\title{
CHARACTER BUILDING DALAM KONSEP PENDIDIKAN IMAM ZARKASYI DITINJAU DARI FILSAFAT MORAL IBNU MISKAWAIH
}

\section{Najwa Mu'minah}

Pondok Pesantren Al-Muhsin, Krapyak Wetan, Yogyakarta

Email: najh_azroque@yahoo.com

\begin{abstract}
Abstrak
Pudarnya nilai-nilai moralitas dalam kehidupan masyarakat, terlebih dalam birokrasi politik dan pemerintahan, ditunjukkan oleh berbagai anomali dan immoralitas, seperti korupsi, sudah menjadi norma dan budaya yang sulit dikendalikan. Kondisi spirit dan moralitas bangsa yang sedemikian ini menunjukkan urgensi pengembangan kembali model pendidikan karakter sebagai upaya national healing. Imam Zarkasyi,pendiri Pondok Pesantren Modern Gontor, menerapkan character building dalam pendidikan modernnya. Ditinjau dari filsafat akhlak Miskawaih, Imam Zarkasyi mengajarkan keutamaan akhlak dengan mentransformasi livingvalues dari Panca Jiwa dan Motto Kemodernan.Upaya pembaharuan sistem, metode, dan kurikulum pendidikan dilakukan dalam rangka pembangunan karakter, dengan menerapkan prinsip jalan tengah (the Golden Mean) Ibnu Miskawaih, tetapi ia dudukkan dalam konteks modernisme pendidikan Islam. Beberapa aspek pendidikan karakter Imam Zarkasy yang sangat mendukung bagiprogram pendidikan karakter dan menemukan relevasinya adalah: pertama, keunggulan wawasan kepemimpinan dalam model pesantrennya; kedua, konsepsi teleologis tentang akhlak mulia sebagai tujuan pendidikan karakter; ketiga, pengembangan metodis melalui lingkungan pendidikan bermodel pondok pesantren agar pendidikan lebih optimal dan efisien; keempat, sumbangan praksis berupa kurikulum yang integral dan komprehensif. Di dalam konsep dan gerakan pembaharuan pendidikan yang ia lakukan, terkandung konsep pendidikan karakter yang cukup matang dan teruji sehingga patut digali manfaatnya oleh bangsa ini.
\end{abstract}

Katakunci: karakter, akhlak, pancajiwa, jalan tengah, pesantren.

\section{Abstract}

Degradation of moral consciousness, especially in the politic and Indonesian government bureaucracy, in recent times that was pictured by various anomalies and immorality, such as a corruption, has become a negative "cultural norm", which seem very difficult to be controlled. The condition of national spirit and morality suggested the need of redevelopment of model of character 
education (character building) as a national healing. Imam Zarkasyi implemented several principles of character building in the Pesantren of Darussalam Gontor. He taught his pupils on the basis of the virtues of the excellences with refer to the Panca Jiwa and the Four Mottos of Modernity of the Pesantren as their living values. His reformative efforts in the context of contemporary Islamic education are actually intended to the development of character, in other words, "character building", by implementing the principle of the Golden Mean of Ibn Miskawaih. Some aspects of Zarkasyi's principles of education that might be supportive for developing the national character education program, and still relevant for today are: firstly, moral education should have the leadership insights; secondly, moral education should have the objective moral values as the teleological purposes; thirdly, moral education should be built through the best environment, in order to be optimized and efficient; and fourthly, moral education curriculum should be integrated and comprehensive. So, the Zarkasyi's concept of character building, and the education movement became the concept of character education that quite mature and should be extracted by our nation.

Keywords: character building, moral, panca jiwa, middle way, pesantren.

\section{PENDAHULUAN}

Penelitian ini berangkat dari permasalahan multidimensional yang dihadapi bangsa Indonesia. Krisis multidimensional begitu mengakar dalam sendi-sendi kehidupan kebangsaan dewasa ini mulai dari aspek ekonomi, politik, hukum, hingga budaya. Krisis ditunjukkan oleh semakin jauhnya perilaku ekonomi, politik, hukum, dan budaya tersebut dari sikap moral yang baik dan normatif. Gejala yang menjadi indikator yang mudah dikenali disini adalah semakin tingginya tingkat korupsi, kolusi, dan nepotisme di Indonesia. Fenomena elitis yang buruk kini sudah membudaya dan menjadi menu utama dalam pemberitaan media masa setiap hari. Kondisi bangsa ini begitu memprihatinkan dan tentu saja memerlukan pembenahan. Yudi Latif menyebut kondisi bangsa ini telah sampai pada titik persamaan dengan yang disebut Machiavelli sebagai citta corrotisima atau "kota korup", atau istilah Al-Farabial-mudunal-jāhiliyyah (Latif, 2007:38).

Menurut penulis, salah satu faktor utama dari krisis multidimensi tersebut adalah karena lemahnya visi dan karakter bangsa. Salah satu 
kelemahan mendasar yang patut mendapatkan sorotan adalah pada sisi mentalitas bangsa atau karakter manusianya. Perbaikan paling mendasar yang perlu dilakukan sekarang adalah berusaha untuk membangun karakter manusia Indonesia yang kuat. Aspek pendidikan tentu menjadi fondasi utama bagi pembangunan karakter. Upaya itu dapat dibakukan dalam istilah yang lebih umum, yakni pendidikan karakter atau pembangunan karakter (character building).

Terkait dengan hal ini, penulis melakukan penggalian ide guna menyokong upaya program pendidikan karakter nasional yang sekarang ini kembali menjadi perhatian pemerintah. Obyek penelitian ini adalah konsep character building dalam pemikiran pendidikan Imam Zarkasyi yang diterapkan di Pondok Modern Darussalam Gontor. Penulis melakukan pendekatan melalui tinjauan analisis dengan menggunakan perspektif pemikiran filsafat pendidikan akhlak Ibnu Miskawaih, filsuf muslim pertama yang membangun teori pendidikan akhlak berdasarkan prinsip-prinsip agama Islam.

Berdasarkan latar belakang di atas maka yang hendak dijawab dalam penelitian ini adalah: (1) Bagaimana filsafat moral menurut Ibnu Miskawaih?; (2) Bagaimana bentuk" character building" dalam konsep pendidikan Imam Zarkasyi?; (3) Bagaimana bentuk "character building" dalam konsep filsafat pendidikan Imam Zarkasyi ditinjau dari filsafat moral Ibnu Miskawaih?

\section{FILSAFAT MORAL IBNU MISKAWAIH}

Ibnu Miskawaih (320-1030 H) merupakan salah seorang tokoh Muslim di bidang filsafat akhlak sekaligus sejarawan yang hidup pada masa pemerintahan dinasti Buwaihi (320-450 H/932-1062 M). Nama lengkapnya adalah Ahmad ibn Muhammad ibn Ya'qub ibn Miskawaih. Akan tetapi ada orang yang menyebutnya dengan Ibn Miskawaih, ada pula yang hanya menyebut dengan nama Miskawaih atau Maskawaih (Suwito, 2004: 67). Nilai-nilai yang baik yang ingin dicapai manusia melalui proses pendidikan, semua terpadu dalam pemikiran filsafat pendidikan moral Ibnu Miskawaih. Istilah "moral" yang lebih tepat untuk Ibnu Miskawaih adalah akhlak, sesuai bukunya Tahdzibul Akhlak 
yang diterjemahkan "falsafat akhlak" atau "hikmatamaliyat" atau "hikmat khuluqiyat". Karakter atau akhlak (bahasa Arab), diartikan Miskawaih: "hal linnafs da'iyah laha ila af'aliha min ghair fikrin wa laa ruwiyatin"(sifat atau keadaan yang tertanam dalam jiwa yang paling dalam yang selanjutnya lahir dengan mudah tanpa memerlukan pemikiran dan pertimbangan lagi (Miskawaih, 1398:40).

Ibnu Miskawaih adalah satu dari filsuf muslim yang dianggap sebagai filsuf akhlak pertama. Lewat bukunya Tahdzib al-akhlaq wa tathir al-a'raq, ia mengembangkan teori pertengahan tentang pendidikan karakter berbasis psikologi manusia yang dipadukan dengan ayat-ayat al-Qur'an dan hadist. Ibnu Miskawaih memandang, karakter (khuluq) merupakan suatu keadaan jiwa (nafsiah) yang mampu bertindak tanpa dipikir atau dipertimbangkan mendalam. Miskawaih memandang karakter ada yang sifatnya alamiah (hereditas), ada juga yang bersifat produktif, artinya dari sebuah proses eksternalisasi dan habitualisasi, yang tercipta melalui kebiasaan dan latihan, akhirnya menjadi karakter (Miskawaih, 1398:56).

Karakter memiliki makna lebih tinggi dari sekedar moral. Pendidikan karakter bukan sekedar pendidikan moral, yang hanya mengajarkan mana yang benar dan mana yang salah, tetapi juga menanamkan kebiasaan (habit) tentang yang baik sehingga siswa menjadi lebih paham, mampu merasakan, dan mau melakukan yang baik (Majid dkk, 2005: 14). Pendidikan karakter (character education atau character building) adalah upaya memengaruhi segenap pikiran dengan sifat-sifat batin tertentu sehingga dapat membentuk watak, budi pekerti, dan kepribadian. Dalam tradisi Islam, character building dibangun berdasarkan sumber yang lengkap, yakni wahyu, intuisi, pendapat, akal, pikiran, panca indera dan lingkungan yang dibangun secara serasi dan seimbang.

\section{Filsafat Ibnu Miskawaih tentang akhlak}

Pemikiran Ibnu Miskawaih tentang akhlak, terutama terdapat dalam kitab Tahdzib al-Akhlak wa Tathir al-A'raq, adalah mengupas secara 
luas dan mendalam masalah akhlak berdasar pada doktrin jalan tengah. Doktrin jalan tengah (The Doctrine of The Mean/The Golden Mean) sudah dikenal para filsuf sebelum Ibnu Miskawaih, seperti Mencius (551-479 SM), Plato (427-347 SM), Aristoteles (384-322 SM), Al-Kindi dan Ibnu Sina. Menurut Miskawaih "pertengahan atau jalan tengah" diartikan keseimbangan, moderat, harmoni, utama, mulia, atau posisi tengah antara dua ekstrem. Dalam kaitannya dengan keutamaan akhlak, jalan tengah diartikan sebagai posisi tengah antara ekstrem kelebihan dan ekstrem kekurangan pada masing-masing jiwa manusia (Suwito, 2004: 91).

Menurut Ibnu Miskawaih, manusia tersusun dari dua aspek mendasar, yaitu aspek jasad (jisim) dan aspek jiwa (nafs).Jiwa adalah aspek ruhaniah, sedangkan jasad adalah aspek materi. Jiwa itu akan kekal, sedangkan jasad akan musnah. Jiwa adalah wawasan spiritual berasal dari pancaran Tuhan, sedangkan unsur jasad manusia berasal dari materi (Suwito, 2004: 77). Jiwa terbagi menjadi tiga, yaitu jiwanatiqah (daya berpikir); jiwa ghadabiyyah (daya marah) atau nafs sabu'iyyah (daya kebuasan), yakni keberanian menghadapi resiko, ambisi kekuasaan; dan, nafs bahimiyyah (jiwa hewani) atau nafs syahwatiyyah yaitu dorongan nafsu atau keinginan, seperti makan, minum, seksualitas serta segala kenikmatan inderawi. Nafsu natiqah berasal dari ruh Tuhan dan karenanya akan kekal; sedangkan nafsu ghadabiyyah dan bahimiyyah berasal dari unsur materi dan karenanya akan hancur (Suwito, 2004: 77).

Kedua nafsu (ghadabiyyahdan bahimiyyah) tersebut memiliki jalinan interaksionis dengan tubuh atau jasad, sehingga dimungkinkan prinsip al-'aqlu saliim fi al-jismi as-saliim, bahwa jiwa yang sehat terdapat pada badan yang sehat (Suwito, 2004: 78). Jiwa natiqah tidak dipengaruhi kondisi jasad, malah jasad bisa menghalangi kesempurnaannya. Jiwa natiqah tidak menjadi kuat dengan kuatnya tubuh, dan sebaliknya. Alat yang diandalkan nafsu natiqah adalah otak (Suwito, 2004: 82). Nafs natiqah memberikan pengaruh daya teoritis ('alimatatau nadzariy) dan daya praksis ('amilat atau amali). Natiqah teoritis (akal teoritis) tidak menyangkut materi, teraktualisasi dalam hal-hal teoritis, tidak bekerja dengan anggota tubuh, sebab ia pada tataran abstrak; dan natiqah praksis (akal 
praksis) menyangkut materi, teraktualisasi dalam hal-hal praksis, bekerja menggunakan otak, dan dibantu indra pengingat (al-quwwatalhafidzat) atau memory (Suwito, 2004: 83-84). Dalam nafs natiqah terjadi gerakan dauriyyah (melingkar), yaitu gerak melingkar natiqah pada dirinya sendiri menuju intelejensia (immaterial) atau menuju materi. Apabila menuju intelejensia maka ia bergerak menuju hikmat yang mendekati 'aql mustafad, mendekat kepada Tuhan, sedang gerak menuju materi sebaliknya, semakin menjauhi Tuhan dan akan membawa kepada kehancuran (Suwito, 2004: 84).

Ketiga nafs (syahwatiyyah, ghadabiyyah, dan natiqah) memiliki jalinan interaksi pada tataran ruhani dalam diri manusia, disebut hubungan ruhaniyah (ittishalruhani). Mengetahui jalinan interaksi ini pun memerlukan usaha ruhani (ihatat ruhaniyyah). Berkat ittishal manusia menjadi manusia yang sesungguhnya. Nafs natiqah merupakan daya ketuhanan (al-quwwah al-ilahiyyah) yang mampu melahirkan berbagai kesadaran dalam diri manusia, untuk menjadi manusia yang hakiki: memiliki perasaan malu, sedih, senang, kemuliaan, baik, dan sebagainya. Nafs ghadabiyyah dan nafs syahwatiyyah tidak mampu melahirkan kesadaran manusia, tetapi lebih kepada fungsi fisik. Jadi, natiqah pemimpin kedua nafsu yang lain, jika kepemimpinan itu berhasil, maka seseorang akan menjadi orang yang berakhlak mulia (Suwito, 2004: 81$82)$.

Manusia terlahir membawa potensi besar, yaitu: ruh ilahi, daya kekuatan nafs natiqah yang memberikan pancaran-pancaran ilahi; ruh thabi'i (alamiah, persepsionis, inderawi) dari nafs ghadabiyyat; dan ruh syaitani dari nafs syahwati. Manusia menjadi "pertemuan antara kenyataan empiris dengan kenyataan ilahiah". Potensi thabi'i dari nafs ghadabiyyat membawa manusia pada kemungkinan memakmurkan alam dan bumi (empiris); potensi syaitani dari nafs syahwati mampu membawa manusia merusak keduanya; potensi ilahi dari nafs natiqah yang menjadi sumber nilai-nilai etis, dan membawa kepada kemuliaan. Ketiga potensi ini akan berkembang seiring aktualisasi dalam diri manusia. Manusia lahir membawa kemungkinan: merusak, memelihara, dan juga berketuhanan (Suwito, 2004: 80 dan 82). 


\section{Konsep insan kamil: manusia berakhlak mulia}

Tiga macam jiwa,yaitu jiwa al-bahimiyyat, jiwa al-ghadabiyyat, jiwa al-natiqat adalah sumber bagi perkembangan perilaku manusia dan kualitas mental manusia. Melalui daya ini manusia mampu mencapai tingkat lebih tinggi, mulai dari tingkat 'aqil hingga tingkat kebajikan mutlak, tingkat malaikat, atau tingkat ketuhanan. Tahap perkembangan daya pada manusia ini menjadi acuan Ibnu Miskawaih membangun gagasan pendidikan akhlak, yaitu proses menguatkan dan meluruskan potensi-potensi manusia agar semakin tinggi kualitas akhlaknya (Suwito, 2004: 88).

Seseorang yang mengembangkan sifat kemanusiaan, kemalaikatan, dan ketuhanan, ia akan menyerupai malaikat, dan semakin dekat dengan Allah Swt. Posisi inilah tingkat yang ideal, manusia yang derajatnya paling tinggi: manusia sempurna atau insan kamil (Suwito, 2004: 87). Tingkat kesempurnaan, kamal atau manusia mulia yaitu tingkat dimana orang mencapai pengetahuan menyeluruh (kulliyat), melihat segala sesuatu pada esensi universal, bukan partikular (juziyyat). Tingkat ideal dicapai melalui proses pendidikan, proses kecintaan akan ilmu pengetahuan yang tinggi (as-syauq ila al ma'arif wa al-ulum). Posisi ideal ini hanya dapat dicapai para filsuf dan para nabi, dengan kemampuan berkontemplasi, menyatukan diri dengan Tuhan. Mereka disebut 'aliman tamman, orang yang sempurna dalam keilmuan dan perilaku. Bedanya, filsuf mendapatkan hikmat dari jalan berfilsafat, berkontemplasi, atau "dari bawah" sedangkan nabi mendapat hikmat dari Tuhan atau "dari atas" (Suwito, 2004: 89-90). Namun Ibnu Miskawaih memandang manusia sebagai makhluk sosial harus berinteraksi sosial. Karenanya ia tidak sepakat dengan pencapaian pengetahuan dengan model pendidikan asosial, model berkhalwat, bertapa, dan mengasingkan diri (Suwito, 2004: 90).

\section{Konsep akhlak dan keutamaannya: teori jalan tengah}

Menurut Ibnu Miskawaih, empat keutamaan akhlak utama (alfadilat), yaitu: kebijaksanaan (al-hikmah), keberanian (as-syaja'ah), kesucian diri (al-'iffah), dan keadilan (al-adalat), yang menjadi induk (pokok) 
dari berbagai perangai atau bentuk akhlak (cabang) yang lain. Agar mendapatkan keutamaan (fadilah), ketiga potensi al-bahimiyyat, al-ghadabiyyat, al-natiqat dalam tubuh manusia tersebut harus digunakan secara seimbang, pertengahan, dan adil.

Jalan tengah dari ketiga keutamaan akhlak, keutamaan hikmah, keberanian, dan kesucian diri, adalah keutamaan keadilan (al-'adalat atau justice). Keadilan adalah kesempurnaan dan pemenuhan ketiga keutamaan tersebut, yang menghasilkan keseimbangan dan persesuaian antara jiwa natiqah, ghadabiyyah, dan bahimiyyah. Keseimbangan tersebut merupakan cara penyatuan, bahwa prinsip utama hidup di dunia adalah pengganti atau bayangan dari keesaan Tuhan. Kesatuan yang seimbang adalah "kesempurnaan makhluk" (perfection of beings), selain juga sebagai "kebajikan yang sempurna" (perfect goodness) (Suwito, 2004: 108-109).

Akhlak tengah selalu dinamis dan fleksibel, karena dapat terus-menerus berlaku sesuai tantangan zaman tanpa kehilangan nilai-nilai esensial dari pokok keutamaan akhlak. Dengan doktrin jalan tengah, manusia tidak akan kehilangan arah dalam kondisi apapun (Nata, 2000: 10-11). Doktrin jalan tengah bersifat relatif, berkembang seiring perkembangan zaman dan ukurannya, dan tidak kaku. Namun tetap, bahwa alat ukur untuk memperoleh sikap pertengahan adalah akal (falsafat) dan syari'at (Suwito, 2004: 94).

\section{Konsep pendidikan akhlak}

Ibnu Miskawaih membangun konsep pendidikan yang bertumpu pada pendidikan akhlak, moral education atau character building. Tujuan dan orientasi pendidikan akhlak adalah mencapai as-sa'adat (kebahagiaan, happiness), yang mencakup makna luas dan menyeluruh: "kebahagiaan" yang mengandung unsur kebahagiaan (happiness), kemakmuran (prosperity), keberhasilan (success), kesempurnaan (perfection), kesenangan (blessedness), dan kecantikan (beautitude) (Nata, 2000: 12). Untuk mencapai tujuan pendidikan akhlak maka semua sisi kemanusiaan mendapatkan materi didikan yang memberi jalan bagi tercapainya tujuan pendidikan,yang juga sebagai bentuk pengabdian (ibadah) kepa- 
da Allah Swt. (Nata, 2000: 12). Materi pendidikan akhlak terdiri atas tiga: kebutuhan jasmani, kebutuhan ruhani, dan kebutuhan sosial. Ketiganya dapat dipenuhi dengan dua kelompok ilmu: al-'ulum al-fikriyyah (akademik) dan al-'ulum al-hissiyyat (inderawi). Apapun ilmu itu, asalkan didasarkan pengabdian tulus kepada Tuhan. Tidak membedakan antara ilmu agama dan ilmu non agama (Nata, 2000: 13).

Peran pendidik di sisi anak didik dan hubungan keduanya, menurut Miskawaih, orangtua adalah pendidik yang pertama, yang mengajarkan tentang syari'at dan peribadatan. Cinta anak didik kepada gurunya juga utama, dan berada di antara kecintaan terhadap orangtua dan kecintaan terhadap Tuhan. Karena guru lebih berperan mendidik murid menuju kebahagiaan sejati; guru mampu membawa anak didik kepada kearifan, kebijaksanaan, hidup dan kenikmatan yang abadi (Nata, 2000: 17). Guru yang demikian adalah guru ideal, predikatnya mencapai taraf kenabian, mu'allim yang hakim atau bijak, yang cintanya di posisi kedua setelah cinta kepada Tuhan. Guru yang tidak memiliki kapasitas tersebut, dipersamakan teman dan karib, yang cintanya di antara posisi guru ideal dan orangtua (Nata, 2000: 19). Hubungan guru dan murid amat penting dan berpengaruh terhadap keberhasilan dalam pendidikan akhlak (Nata, 2000: 20). Perihal lingkungan pendidikan, Miskawaih menekankan fungsi integrasi lingkungan bagi proses pendidikan secara keseluruhan. Lingkungan pendidikan adalah masyarakat umumnya, lingkungan sekolah, lingkungan pemerintahan, sampai lingkungan rumah tangga dan lingkungan yang lain, yang satu sama lain saling mempengaruhi terhadap terciptanya lingkungan pendidikan (Nata, 2000:22).Ibnu Miskawaih berpendapat, perbaikan akhlak bukan bawaan atau warisan, yang tidak memerlukan proses pendidikan, tetapi dapat diusahakan atau dapat menerima perubahan yang diusahakan (Nata, 2000:22).

Metode Ibnu Miskawaih dalam proses pendidikan akhlak, yakni: (1) Metode alami, melakukan pendidikan akhlak terhadap hal-hal yang potensial ada dalam diri manusia, menyangkut nafsu atau jiwa syahwatiyyah (seperti makan, minum, dan etiket sehari-hari), jiwa ghadabiyah (dengan cara memberikan cinta kasih), dan jiwa natiqah (dengan cara 
menciptakan rasa cinta pengetahuan). (2) Metode bimbingan, artinya memberikan nasehat dan instruksi tentang kebaikan dengan berbicara dan olah kata, seperti membimbing dalam hal ibadah, interaksi yang baik antara guru dengan murid. (3) Metode ancaman, hardikan atau hukuman, diberikan apabila murid tidak mau mengikuti nilai-nilai yang diajarkan, untuk memberikan penyadaran. (4) Metode pujian diberikan apabila anak didik mampu atau mau melaksanakan ajaran atau nilai yang sudah diajarkan. Menurut Ibnu Miskawaih, metode al-'adat wa aljih (pembiasaan dan pelatihan) perlu digunakan sungguh-sungguh dan terus-menerus agar memperoleh keutamaan dan kesopanan yang sesuai dengan keutamaan jiwa; dan membuat orang lain cerminan bagi perilaku setiap individu, sehingga setiap orang bisa berkaca pada pengalaman dan kehidupan orang lain (Nata, 2000: 23).

\section{CHARACTER BUILDING}

\section{DALAM KONSEP PENDIDIKAN IMAM ZARKASYI}

Imam Zarkasyi dilahirkan pada 21 Maret 1910 di desa Gontor, sekitar 11 kilometer dari arah selatan kota Ponorogo Jawa Timur dari pasangan Kyai Santoso Anom Besari dan Nyai Sudarmi. Keduanya adalah pemimpin terakhir pesantren "Gontor Lama" yang sudah eksis semenjak didirikan oleh Kyai Sulaiman Djamaluddin, cabang pesantren Tegalsari Ponorogo yang masyhur di seluruh pelosok Jawa pada masa abad 18. Gontor lama pernah mengalami kejayaan di masa Kyai Archam Anom Besari, hingga mengalami kemunduran dan semakin mundur sepeninggal Kyai Santoso Anom Besari, generasi terakhir, ayah Imam Zarkasyi (Tim, 1996: 3). Pendidikan Imam Zarkasyi dimulai dengan belajar ilmu agama di pondok pesantren dan sekolah pada usia kurang lebih 10 tahun di Desa Nglumpang (desa sebelah timur Gontor). Belum genap usia 16 tahun, Imam Zarkasyi muda melanjutkan belajarnya di beberapa pesantren yang ada di daerah kelahirannya, seperti Pesantren Josari, Pesantren Joresan, dan Pesantren Tegalsari (Tim, 1996: 18). Dari beragam pengalaman di beberapa pesantren tersebut Imam Zarkasyi mengenyam banyak tentang “kepesantrenan” yang metode pembelajarannya tergolong masih tradisional. Imam Zarkasyi 
membangun kembali lembaga pendidikan "Gontor Baru" pada 9 Oktober 1926 bersama kedua saudara (K.H.Ahmad Sahal dan K.H. Zainuddin Fannani, yang akrab disebut Trimurti), yang cikal bakalnya sudah tertanam semenjak "Gontor Lama", namun dengan pembaharuan di berbagai sisi. Pengalaman pendidikan "pesantren klasik" dipadukan dengan pengalaman "pesantren modern" di Padang, ia padukan dan ia terjemahkan dalam wujud pesantren modern yang unik dan bertahan hingga kini, Pondok Modern Darussalam Gontor. Imam Zarkasyi menghembuskan nafas terakhir pada 30 April 1985, ketika Pondok Gontor telah berusia lebih dari setengah abad.

\section{Konsep pendidikan Imam Zarkasyi}

Pendidikan bagi Imam Zarkasyi sebagai proses pendidikan jiwa dan mental untuk membentuk insan atau pribadi merdeka. Konsep pendidikannya adalah pembaharuan kritis, khususnya terhadap pendidikan feodalisme. Konsep pesantren modern menjadi alternatif, dengan perombakan terkait sistem pendidikan, metode pengajaran, dan kurikulumnya, dalam hal ini adalah Pesantren Modern Gontor (Zarkasyi, 1996: 368). Secara garis besar konsep pendidikan pesantren Imam Zarkasyi dapat dibagi menjadi empat bagian, yaitu:

1. Pembaharuan metode dan sistem pendidikan

Metode dan sistem pendidikan di Gontor adalah sistem pendidikan klasikal yang terorganisasi dalam penjenjangan kelas dalam jangka waktu tertentu (5-6 tahun), dan memperkenalkan kegiatan ekstrakurikuler di luar jam pelajaran. Dalam semua aktivitas, santri diharuskan tinggal di pondok pesantren (boarding school). Sistem pendidikan asrama, sebagai ciri khas pesantren, dipertahankan agar tujuan dan asas pendidikan dapat dibina dan dikembangkan lebih efektif dan efisien.

Pola dan irama kegiatan pesantren berlangsung alamiah dengan disiplin ketat, dan tanpa peraturan tertulis. Peraturan diproses menjadi bagian dari kualitas kesadaran, pikiran dan naluri, dijadikan pedoman santri membangun kehidupan sosialnya di pesantren. 
Perpaduan the day school system dengan sistem asrama tidak menghilangkan elemen penting dalam tradisi pesantren, yaitu pengkajian kitab-kitab Islam klasik (kitab kuning). Esensi pelajaran agama yang menjadi inti kitab kuning itu tetap ada dan dikemas dalam buku-buku yang lebih praktis dan sistematis disesuaikan jenjang pendidikan santri. Pada jenjang akhir, santri diberi kesempatan membongkar dan memahami kitab-kitab kuning dalam jumlah besar dari berbagai disiplin ilmu agama. Dengan kemampuan bahasa Arab yang dimiliki sejak kelas satu, santri dapat membaca dan memahami kitab-kitab tebal itu, tanpa harus dibantu kyai sebagaimana pada metode sorogan atau wetonan di pesantren tradisional. Program itu diberi nama Fathul Kutub. Imam Zarkasyi juga menganjurkan para santri agar mereka memiliki, membaca, dan memahami kitab-kitab yang dipakai di pesantren tradisional, sepertiFatbul Qarib, Fatbul $M u^{\prime}$ in, I'anatul Thalibin dan sebagainya (Zarkasyi dkk, tt: 15).

2. Pembaharuan kurikulum

Kurikulum di Pondok Pesantren Modern Gontor adalah 100\% pendidikan umum dan $100 \%$ pendidikan agama. Di samping pelajaran tafsir, hadits, fiqih, ushulfigh, juga ditambah pengetahuan umum seperti ilmu alam, ilmu hayat, ilmu pendidikan, ilmu jiwa, dan sebagainya. Pelajaran bahasa, Arab dan Inggris, menjadi ciri khas pesantren Gontor (Yunus, 1979: 251). Dalam penguasaan bahasa ini, semboyan Imam Zarkasyi: al-kalimah al-wahidah fi alf jumlatin khairun min alfi kalimah fi jumlatin wahidah (kemampuan memfungsikan satu kata dalam seribu susunan kalimat lebih baik daripada penguasaan seribu kata secara hafalan dalam satu kalimat saja) (Djumhur dkk, 1976: 193; Nata, 2000: 207).

Diberikan juga pendidikan kemasyarakatan dan sosial untuk melangsungkan kehidupan sosial ekonominya. Para santri dilatih mengembangkan cinta kasih yang mendahulukan kesejahteraan bersama daripada untuk pribadi, kesadaran pengorbanan yang diabdikan demi kesejahteraan masyarakat, khususnya umat Islam (Ziemek, 1986: 159) \& (Nata, 2000: 207). Diajarkan pelajaran ekstra seperti etiket atau tata krama yang berupa kesopanan batin menyang- 
kut akhlak dan jiwa dan kesopanan lahir termasuk gerak-gerik, tingkah laku, bahkan berpakaian (Ali, 1991:53).

3. Pembaharuan struktur dan manajemen pesantren

Demi kepentingan pendidikan dan pengajaran Islam, Imam Zarkasyi dan dua saudaranya mewakafkan Pondok Pesantren Gontor kepada lembaga Badan Wakaf Pondok Modern Gontor. Secara kelembagaan pondok tidak lagi milik pribadi sebagaimana pesantren tradisional, tetapi menjadi miliki dan tanggung jawab umat Islam. Lembaga badan wakaf menjadi badan tertinggi di pondok yang bertanggung jawab mengangkat kyai untuk masa jabatan lima tahun. Kyai bertindak sebagai mandataris dan bertanggung jawab kepada Badan Wakaf. Untuk ini Badan Wakaf memiliki lima program: bidang pendidikan dan pengajaran, bidang peralatan dan pergedungan, bidang perwakafan dan sumber dana, bidang kaderisasi, serta bidang kesejahteraan (Nata, 2000: 208).

Dengan struktur kepengurusan yang demikian, maka kyai dan keluarga tidak punya hak material dari pesantren. Kyai dan guruguru tidak mengurusi uang dari para santri, mereka tidak pernah membedakan para santri kaya maupun miskin. Urusan keuangan menjadi tanggung jawab petugas kantor tata usaha yang terdiri dari beberapa orang santri senior dan guru yang secara periodik bisa diganti. Dengan demikian, pengaturan jalannya organisasi pendidikan menjadi hal yang dinamis, terbuka, dan obyektif (Nata, 2000: 208209).

4. Pembaharuan dalam pola pikir santri dan kebebasan pesantren

Santri ditanamkan jiwa berdikari dan bebas, dengan belajar dan berlatih mengurus kepentingannya sendiri, bebas menentukan jalan hidupnya di masyarakat.Pondok pesantren sebagai lembaga pendidikan harus tetap independen dan tidak bertanggung jawab pada pihak lain (Zarkasyi I. tt: 11-14). Gagasan ini direalisasikan dengan menciptakan Pondok Modern Gontor steril dari kepentingan politik dan golongan apapun, dengan semboyan "Gontor Berdiri di Atas dan Untuk Semua Golongan". 


\section{Akhlak menurut Imam Zarkasyi}

Bagi Imam Zarkasyi, etika tidak bisa dilepaskan dari agama, sebab dalam terminologi Islam, etika terkait erat dalam salah satu dari tiga aspek pokok dari agama, yakni akhlak, keyakinan (i'tiqad atau aqidah) dan rasa atau perasaan ('atifah). Akhlak adalah "sesuatu yang ideal" dalam berperilaku bagi penganut keyakinan agama atau seorang muslim (Tim, 1996: 272). Imam Zarkasyi mengatakan, "Akhlak adalah petunjuk dan pedoman, yang harus kita ikuti dalam kehidupan kita. Pedoman-pedoman itu, bagi umat Islam, diambil dari kitab suci dan hadist-hadist" (1946). Etika yang menjadi acuan adalah yang berdasarkan agama atau etika religius, bukan pandangan, aliran atau filsafat tertentu.

Peran akhlak sebagai penilaian yang ideal, absolut, paling benar menurut ukuran agama. Ajaran akhlak ideal sebagai tolok ukur, "ancerancer", atau pedoman dan arah yang "sempurna", tidak bisa begitu saja diterapkan dalam masyarakat. Sehingga perlu "pertimbangan yang dalam", secara matang dalam hal akhlak dan perilaku. Ajaran perilaku ideal atau "akhlak yang penuh keutamaan", adalah sebagai norm atau ukuran, tetapi penerapan akhlak bisa berubah tergantung kondisi dan waktu, juga sudut pandang. Oleh karena itu, akhlak tidak bisa dilepaskan dari pemikiran dan pengetahuan (Tim, 1996: 276).

\section{IMPLEMENTASI CHARACTER BUILDING \\ DALAM KONSEP PENDIDIKAN IMAM ZARKASYI PADA SISTEM PENDIDIKAN GONTOR}

\section{Sistem pendidikan integral}

Pondok Modern Darussalam Gontor lahir pada tahun 1926 di tengah pertemuan dua sistem pendidikan: pendidikan modern Barat dan pendidikan modern Islam yang dimotori tokoh-tokoh gerakan modernis dan reformis muslim. Gontor baru, pembaharuan dari pondok Gontor lama, dibangun di atas warisan nilai-nilai luhur pesantren yang diintegrasikan dengan sistem dan metode pendidikan modern. Idealisme, jiwa dan falsafah hidup pesantren tetap menjadi ruh Pondok Gon- 
tor dengan penanaman yang lebih efektif dan efisien dengan menggunakan sistem dan metode pendidikan modern (Tim, 1996: 67).

Prinsip integrasi sistem pendidikan yaitu, semua yang ada di pondok sengaja diciptakan untuk pendidikan. Semua kegiatan di pondok yang bersistem madrasah dan berjiwa pesantren ini saling terkait dan saling mendukung (Tim, 1996: 67). KH. Abdullah Syukri Zarkasyi berpandangan bahwa pendidikan integral itu menciptakan orang yang berkarakter. Karakter dibangun bukan sekedar dengan pembelajaran, akan tetapi juga pengajaran, pelatihan, pembiasaan, dan pembinaan. Pendidikan agama dan moralitas diintegrasikan (Zarkasyi, 2005: 19). Sistem pendidikan integral ini diimplementasikan dalam kegiatan santri sehari-hari dimulai dari bangun tidur hingga tidur lagi, berupa kegiatan dengan nuansa penuh pendidikan. "Apa yang dilihat, didengar, dan dirasakan di Gontor adalah pendidikan".

\section{Integrasi sistem madrasah dan pesantren}

Integrasi pendidikan sebagai sistem pembangunan karakter di atas terimplikasikan dalam wujud integrasi model sistem madrasah dan sistem pesantren. Madrasah berarti tempat memberikan pelajaran, kurikulum didominasi ilmu-ilmu agama. Namun, tidak ada dokumen tertulis rincian kurikulum madrasah mengingat madrasah tidak terikat secara organisatoris antara satu madrasah dengan lainnya karena setiap madrasah bebas menentukan materi dan sistem pengajarannya (Zarkasyi, 2005:47).

Imam Zarkasyi memilih model Normal Islam School (Kulliyyatul Mu'allimin al-Islamiyyah) yang didirikan gurunya, Mahmud Yunus, di Padang Panjang, Sumatra Barat, yang tersentuh pembaruan dengan kurikulum yang baik, meliputi ilmu pengetahuan umum, bahasa Arab dan bahasa Inggris. Metode dan sistem pendidikan "klasikal” yang terpimpin secara terorganisir dalam bentuk penjenjangan kelas dalam jangka waktu yang ditetapkan (Ali, 1991: 53) sebagai pembaharuan untuk efisiensi pengajaran. Kulliyyatul Mu'allimin al-Islamiyyah (KMI) yang didirikan Imam Zarkasyi dikembangkan ke arah tujuan pokok pendidikan pesantren, yaitu tafaqquh fi ad-din, guna mencetak ulama 
dan tokoh masyarakat dengan menerapkan sistem belajar yang efisien dan efektif (Tim, 1996: 49). Sistem pesantren yang dipakai sebagaimana umumnya, yakni lembaga pendidikan Islam dengan sistem asrama atau pondok, dengan kyai sebagai figur sentral, masjid sebagai pusat kegiatan, dan pengajaran agama Islam dibawah bimbingan kyai yang diikuti santri sebagai kegiatan utamanya (Tim, 1996: 556).

\section{Integrasi kurikulum}

Kurikulum di Pondok Modern Darussalam Gontor adalah kurikulum tersembunyi (the hidden curriculum) yangmenjadi kelebihan (nilai plus) dalam membentuk karakter santrinya. Pada tahap awal perintisan Imam Zarkasyi menerapkan kurikulum Normal IslamSchool yang didirikan Mahmud Yunus. Juga ada pengaruh gurunya, Al-Hasyimi, di Madrasah Arabiyah Islamiyah di Solo, dalam mendesain perubahan pesantren yang sebelumnya dikelola kakaknya, Ahmad Sahal dan Zainuddin Fannani (Zarkasyi, 2005: 114).

Dalam character building, kurikulum tersembunyi atau the hidden curriculum lebih ditekankan dan lebih banyak berpengaruh bagi pribadi santri. The hidden curriculum, sebagai kurikulum yang tidak tertulis dan terencana, adalah ajang dan proses internalisasi nilai, pengetahuan, dan ketrampilan bagi santri. Kurikulum ini mengintegrasikan pelajaran umum dan agama, sehingga ada keseimbangan antara ilmu pengetahuan umum dengan agama. Keseimbangan aspek soft skill bahasa, penggunaan bahasa pengantar Arab dan Inggris secara teratur, dan kedisiplinan santri tinggal di asrama, menjadi corak khas Pondok Gontor (Ali, 1996: 948). Ditambah pelajaran praksis, santri terlibat langsung dalam struktur dan manajemen pondok pesantren, membuat santri memiliki karakter, kecerdasan, kecakapan, dan keterampilan, tanpa melupakan transformasi pengajaran akademik resmi.

Integrasi kurikulum formaldengan kurikulum tersembunyi menjadi paduan utuh dalam sistem pendidikan pondok. Imam Zarkasyi (Zarkasyi I.tt: 2) menyatakan bahwa pelaksanaan pendidikan akhlak (character building) dan akal (akademik) tidak cukup hanya dengan ka- 
lam (pemberitahuan), tetapi juga dengan memberi keteladanan dan membentuk lingkungan pendidikan yang baik. Selain itu, yang menjadi hakekat kurikulum adalah apa yang dilihat santri, apa yang didengar dari setiap gerak dan suara dalam pesantren itu menjadi unsur yang terpadu (integrated) menjadi pendidikan akhlak dan pendidikan akademik.

\section{Integrasi nilai: motto dan panca jiwa pondok}

Integralitas nilai pendidikan berupa panca jiwa yang dibangun agar para santri memahami makna, nilai, dan tujuan pendidikan yang sebenarnya; bahwa pendidikan yang terpenting adalah akhlaqul karimah dan kepribadian, serta didukung intelektualitas yang memadai. Begitu pentingnya akhlaqul karimah atau pribadi akhlaqi, sehingga konsep itu terpatri dalam motto Pondok. Empat motto atau pilar bagi pembentukan pribadi dalam pendidikan integral Pondok Modern Darussalam Gontor, yakni mencetak pribadi yang: berbudi tinggi, berbadan sehat, berpengetahuan luas, dan berpikiran bebas. Karakter pribadi yang berakhlak mulia (akhlaq karimah), berbadan sehat (ajsam sahihah), berpengetahuan luas ('ulum wasi'ah), dan bebas dalam berpikir (afkar hurrah) sebagai aspek teleologis personal didasarkan pada nilai-nilai pendidikan integral, di Gontor dikenal dengan “Panca Jiwa Pondok Modern”. Panca jiwa adalah local values yang terintegrasi dan diterapkan secara konsisten dalam wadah Pondok. Panca jiwa dijadikan sumber ide dan konsep dalam pendidikan modern (Haikal, 1996, 882), sebagai spirit nilai dalam gerak dan pembangun karakter santri. Lima nilai ideal panca jiwa merupakan sumber semangat dalam menjalani pendidikan, mencakup keikhlasan, kesederhanaan, berdikari, ukhuwah islamiyah, dan jiwa bebas.

Keikhlasan sebagai ruh (spirit) utama dalam menggerakkan aktivitas pondok. Segala aktivitas pondok adalah untuk ibadah dan pendidikan. Sikap ikhlas adalah sikap tanpa pamrih (Jawa: sepi ing pamrih rame ing gawe). Kyai ikhlas dalam mengajar dan mendidik, para guru ikhlas dalam mengajar dan mendidik, dan murid ikhlas diajar, belajar, dan dididik (Tim, 1996: 427). Kesederhanaan adalah sebagai unsur kekuatan dan ketabahan hati dalam menjalani segala bentuk kesulitan dan rintangan selama dalam pendidikan pondok pesantren. Bukan meneri- 
ma kemiskinan dan hidup serba kekurangan dan penuh keterbatasan, melainkan hidup elegan dan sederhana sebagai bangunan kekuatan mental dan karakter yang kuat untuk menjalani hidup (Tim, 1996: 428). Berdikari (sikap "berdiri di atas kaki sendiri") sebagai jiwa kesanggupan menolong diri sendiri (self help) dan juga orang lain. Santri dilatih menangani seluruh kepentingannya sendiri. Hal ini dicontohkan oleh eksistensi pondok yang tidak menyandarkan diri pada bantuan dan belas kasihan orang lain (Tim, 1996, 428). Seluruh aktivitas yang menunjang eksistensi pendidikan pesantren dikerjakan secara mandiri. Ini yang nantinya akan menciptakan etos kerja yang besar dalam diri anak didik (Alhamuddin, $1428 \mathrm{H}$ : 222).

Sementara $u k h u w a h$ adalah jiwa persaudaraan, solidaritas, tenggang rasa, empati, persatuan, dan gotong-royong, yang terjalin secara demokratis antarsesama. Segala kesenangan dan kesedihan saling dibagi dan dirasakan bersama. Dengan pendidikan persaudaraan ini diharapkan kelak santri akan dapat mewarnai persaudaraan di masyarakat setelah menyelesaikan pendidikan (Tim, 1996: 428). Sedangkan Jiwa bebas adalah jiwa yang bebas berpikir dan berbuat, menentukan masa depan, memilih jalan hidup di masyarakat dengan kebesaran hati dan optimisme. Bahkan dimaknai bebas dari pengaruh kolonial dan pengaruh asing (Tim, 1996: 428). Kebebasan dalam panca jiwa harus dikembalikan pada keasliannya, yakni bebas di dalam garis-garis disiplin positif, dengan penuh tanggung jawab baik dalam kehidupan pesantren itu sendiri maupun dalam masyarakat (Alhamuddin, $1428 \mathrm{H}: 225)$.

\section{Menerapkan metode pendidikan moral}

Imam Zarkasyi menampik pendidikan model "instan": "pondok pesantren bukanlah sebagai bengkel yang begitu saja bisa merubah perilaku seseorang yang sudah "rusak" menjadi "baik" (Sirojuddin, 1996: 777). Ia menekankan pentingnya partisipasi subyek didik: "jadi (pada hakekatnya) yang membikin pondok itu adalah santri-santri sendiri. Bukan kyai yang mendirikan, bukan kyai yang membikinkan pesantren!" (Haikal, 1996: 885). Ia mengatakan tentang filosofi pengajaran populer: "al-thariqah ahammu min al-maddah" (metodologi itu lebih penting daripada materi) (Haikal, 1996: 828). 
Ia menolak simplifikasi kehidupan pesantren, dan mengukuhkan kesadaran pentingnya proses pendidikan, model pembelajaran, dan pendidikan karakter yang baik. Sebagai kyai pemimpin pesantren, Imam Zarkasyi terlibat langsung dalam ketiga hal tersebut. Dalam mendidik dan membangun karakter serta moral anak didik ia menerapkan metode 6P. Pertama, peneladanan (giving example and figure). Pendidikan moral dan pengajaran tidak cukup dengan kata-kata dan anjuran, keteladanan paling utama. Dalam hal ini teladan dalam menerapkan panca jiwa: ikhlas, sederhana, etos kerja (berdikari), persaudaraan, dan bebas. Kedua, pembentukan lingkungan (milieu). Kalimat: "kullu maa samiuhu min harokatin au ashwatin fihadzal-ma'had yakunu 'amilan min 'awamili tarbiyah" menjadi acuan pembentukan lingkungan pesantren. Corak pendidikan totalitas:"Yang terpenting (bagi setiap guru) adalah selalu menggunakan setiap moment untuk menanamkan karakter yang mulia dan moral yang baik kepada anak didik". Ketiga, pelatihan dan pembiasaan (training and habit). "Semua aktifitas di pondok ini adalah pendidikan dan pelatihan dan disiplin untuk hidup di masyarakat kelak" (Zarkasyi I.tt.: 36). Keempat, pembimbingan (guidance) dalam pembentukan karakter dan moral santri, memberikan nasehat, arahan, semangat, dan seterusnya. "Guru wajib menanamkan kepada setiap pribadi santri keimanan, cinta agamanya, dan keikhlasan dalam bekerja, dan juga wajib untuk menanamkan budi pekerti yang baik dalam pribadi setiap santri setiap saat" (As-Sidqy, 2004: 55). Tanggung jawab pembimbingan dan pengasuhan sangat ditekankan, baik di luar maupun di dalam kelas. Kelima, perhatian (care and interest); dengan perhatian (attention and careness) pendidik akan memahami betul suasana dan kondisi anak didiknya, kelebihan dan kekurangannya, sehingga anak didik merasa betul-betul dibimbing pendidiknya, dan ini menciptakan hubungan harmonis antara kyai dan santri. Terakhir, keenam, penghukuman (punishment). "Siapa yang tidak mematuhi disiplin, tentu ia harus menerima konsekwensinya (yaknihukuman)" (Zarkasyi I.tt.:33).

\section{Mengajarkan kaderisasi kepemimpinan}

Konsep kepemimpinan transformasional, dimotori kyai sebagai pemimpin pondok diinternalisasikan ke dalam lembaga atau institusi. 
Dua aspek mendasar, yaitu aspek metode dan aspek sarana. Secara metode, kyai mentransformasikan nilai-nilai kepemimpinan dan membangun mentalitas pemimpin dalam diri setiap santri atau anak didik melalui 7P: pengarahan, pelatihan, penugasan, pembiasaan, pengawalan, keteladanan atau uswah khasanah, serta pendekatan. Sedangkan dalam aspek media (material) kyai mengkader santri sebagai calon pemimpin dengan menerapkan beberapa metode pengkaderan pemimpin dalam kegiatan ekstrakurikuler selama di pondok. Setiap kegiatan didasari Panca Jiwa, Falsafah, dan Motto Pondok, yang ditanamkan dalam kehidupan santri di bawah bimbingan kyai (Zarkasyi A.S., 2005: 120). Semua kegiatan dikelola santri secara self-governance atau self-management.

\section{CHARACTER BUILDING}

\section{DALAM KONSEP PENDIDIKAN IMAM ZARKASYI} DITINJAU DARI FILSAFAT MORAL IBNU MISKAWAIH

\section{Tujuan pendidikan: akhlak mulia}

Titik fokus utama pendidikan Imam Zarkasyi dan Ibnu Miskawaih yakni tujuan, berupa pencapaian akhlak mulia. Akhlak mulia diterjemahkan Imam Zarkasyi ke dalam peringkat pertama motto pendidikan berbudi tinggi. Meski basis ontologinya berbeda, sebagai insan kamil-nya pendidikan karakter Imam Zarkasyi, motto Pondok Pesantren Gontor bisa dipersepsikan sebagai sebuah titik tujuan, selain difungsikan sebagai pedoman dalam pendidikan. Dalam arti tujuan, seluruh proses pendidikan Pondok untuk menciptakan kader-kader umat yang memiliki empat karakter ideal: yaitu manusia berbudi tinggi (akhlaqul karimah), berbadan sehat (sehat jasmani), memiliki pengetahuan luas (broadknowledge), dan memiliki jiwa bebas (tidak terikat dan tertindas).

Dengan terminologi teori Ibnu Miskawaih, titik ideal dalam motto Imam Zarkasyi tersebut adalah maqam dimana santri mampu memiliki daya kejasmanian (al-idrak al-jismani) dan juga daya ruhani (al-idrak ar-ruhani), memiliki wawasan spiritual tinggi, memiliki quwwatul fikr, 
juga memiliki hikmat utama berupa husnul khuluqi atau budi yang luhur, sebuah kemampuan praksis yang mampu dicapai oleh nafs natiqah. Jalinan yang sehat antara badan, perilaku, pengetahuan, dan kebebasan seperti diharapkan Imam Zarkasyi dalam mottonya adalah titik ketika seseorang memiliki hubungan ruhaniah yang sehat atau ittishal ruhaniyat antara ketiga bagian nafsu atau jiwa dalam diri manusia.

Sebagaimana Miskawaih yang memandang daya natiqah harus menjadi pemimpin, mendominasi, dan mengontrol nafs ghadhabiyyat maupun nafs syahwatiyyah, menurut Imam Zarkasyi, akhlak atau budi luhur harus menjadi fondasi utama dalam karakter seseorang, sehingga budi yang tinggi atau akhlak yang baik lebih diutamakan daripada pengetahuan yang luas. Di Gontor, prinsip ini diterjemahkan dalam "sirotul mar'i tumbi'u min sarirotihi"; bahwa karakter terdalam manusia (internal beauty of man) bisa terbaca dari perilaku luarnya. Dari perilaku itulah ittishal ruhaniah manusia akan terbaca, artinya pola perilaku yang buruk dan jahat menunjukkan kualitas dan wawasan spiritual yang rendah.

Corak khusus konsep akhlak Imam Zarksyi adalah kaitan erat akhlakmulia dengan masyarakat. Ia menekankan pentingnya akhlak mulia sebagai idealitas dan peran sosial bagi perbaikan akhlak di masyarakat. Imam Zarkasyi sepakat dengan Aristoteles, bahwa jiwa sosial adalah fitrah, dan manusia adalah masyarakat yang secara kodrati bermasyarakat (man is born as a social being) (Zarkasyi I., 1996: 294). Akhlak mulia memiliki peran yang besar dalam masyarakat. Bagi Imam Zarkasyi akhlak terkait erat dengan, bahkan unsur utama dari,agama. Misi utama agama adalah perbaikan akhlak umat (liutammima makarimal akhlaq). Misi pesantren Gontor menjadi ladang kaderisasi bagi perbaikan masyarakat. Ini sulit dipahami dari perspektif Ibnu Miskawaih yang melihat akhlak sebagai kualitas ruhaniah saja dan, boleh jadi, cenderung sufistis egoistis.

Imam Zarkasyi, sebagaimana Ibnu Miskawaih, percaya bahwa perbaikan akhlak dan perubahan akhlak menuju kemuliaan itu mungkin (probable) dalam diri seseorang melalui proses pendidikan. Ibnu 
Miskawaih meyakini bahwa akhlak tidak saja aspek thabi'i, alamiah, given, atau heredistik, tetapi juga dapat dibentuk melalui proses yang tidak alamiah, willed, atau produktif, yaitu melalui proses pendidikan. Itulah sejatinya yang dilakukan Imam Zarkasyi dengan mendirikan Pesantren Gontor (namanya diambil dari kata "nggon kotor"), dengan tujuan untuk perbaikan masyarakat.

Untuk mencapai derajat kamal atau kesempurnaan akhlak harus didukung kemauan serta kesadaran yang tinggi dari pribadi itu sendiri. Gerak dalam pikiran Imam Zarkasyi dimaknai dalam arti ruhani berupa gerak dauriyah sebagai aktualisasi nafs natiqah, tetapi juga benarbenar gerak secara kongkrit. Gerak dauriyah yang berupa aktualisasi ruhani (dari internal ke eksternal), tetapi benar-benar melalui aspek praksis yang inderawi. Proses akhirnya adalah proses internalisasi (dari eksternal ke internal), melatih sikap dan disiplin hidup yang keras dan kuat. Karakter tafaqquh fiddin atau tholabul 'ilmi menjadi salah satu tolok ukur santri ideal Imam Zarkasyi. Inilah yang juga menjadi perhatian Ibnu Miskawaih, bahwa pada akhirnya salah satu karakter manusia yang berakhlak mulia adalah manusia yang benar-benar memiliki rasa cinta yang tinggi terhadap ilmu, atau assyauq ila al-' ulum wal ma'arif (Suwito, 2004: 89). Niat dan dasar kecintaan ilmu itulah, sebagaimana ditanamkan Miskawaih, yang membuat semangat pengabdian karena ilmu itu sendiri dan karena semangat menjalankan perintah Tuhan yaitu thalabul ilmi dan yatafaqqahufi al-din. Berilmu pengetahuan luas, berbadan sehat, berjiwa bebas, dan berbudi tinggi atau berakhlak mulia adalah karakter pribadi yang ingin diwujudkan Imam Zarkasyi dalam pendidikan, yang dalam bahasa Miskawaih disebut insan kamil.

\section{Panca jiwa sebagai jalan tengah}

Dari kacamata Ibnu Miskawaih, pendidikan karakter yang ditanamkan Imam Zarkasyi adalah pendidikan yang menawarkan nilai-nilai moral yang merupakan nilai ideal sesuai prinsip wasatiah (jalan tengah). Hakekat pesantren sebagai sebuah lembaga pendidikan terletak pada isi dan jiwa-nya. Isi dari pondok pesantren adalah pendidikan mental dan karakter (Zarkasyi I., 1996: 426). Jiwa pesantren yang utama 
(panca jiwa) ditinjau dari teori jalan tengah Ibnu Miskawaih adalah sebagai berikut:

Jiwa keikhlasan adalah satu nilai keutamaan yang merupakan jalan wasatiah di antara dua titik ekstrim, rasa pamrih di satu sisi, dan rasa melas (Jawa: nelongso) di sisi lain. Inilah nilai utama yang seharusnya melandasi seluruh proses pendidikan, yang akan menciptakan unsur pokok pendidikan yang berkualitas, yakni hubungan yang berkualitas antara guru dan murid. Dari persepsi Ibnu Miskawaih, hubungan yang berkualitas itu adalah ketaatan yang baik oleh murid terhadap guru teladan. Sedangkan Jiwa kesederhanaan adalah nilai keutamaan yang merupakan jalan wasatiyah di antara dua titik ekstrim, berlebih-lebihan dan kekurangan. Kesederhanaan adalah sikap yang elegan dan wajar (fair), dan bukan sikap yang overkonsumtif atau overpovertif, yang mendorong model pendidikan yang tidak glamor dan penuh keberlimangan, bahkan akan merubah unsur pendidikan dari sikap yang konsumtif menuju sikap yang produktif, dan dari sikap yang povertif menjadi kreatif. Dalam istilah Ibnu Miskawaih, jiwa kesederhanaan akan mendorong interaksi yang sehat antara nafsu syahwat dan nafsu sabu'iah dan mampu mengontrol keduanya, sehingga anak didik akan memiliki keutamaan (fadhilat) berupa daya kreatifitas, atau daya idrak ruhani seperti tafakkur (berpikir-pikir), takhayyul (khayal) dan imajinasi.

Jiwa berdikari, jiwa kesanggupan untuk menolong dan menghidupi diri sendiri. Istilah ilmiah populernya adalah daya kekuatan untuk survival. Ini adalah jalan wasatiyah yang ditempuh oleh Imam Zarkasyi di antara dua titik ekstrim, yaitu jiwa yang lemah dan jiwa yang imperial. Imam Zarkasyi bercita-cita menciptakan orang-orang yang memiliki karakter dan mental yang tangguh, yang hidup dan menghidupi tanpa menggantungkan pada "liyan" atau pemerintah melalui sistem pendidikan pesantren yang unggul. Sementara itu, jiwa ukhuwah islamiah yang demokratis. Ini adalah jalan tengah atau wasatiyah antara separatisme egoistik dan fanatisme. Suasana pendidikan yang timbul dari jiwa $u k h u w a h$ islamiah adalah suasana pendidikan yang penuh dengan rasa persatuan dan gotong-royong, persaudaraan, akrab, tidak saling menghina satu sama lain yang berbeda suku, saling merasakan kese- 
nangan dan kesedihan orang lain, saling membantu ketika saudara yang lain sedang ditimpa musibah, dan merasa memiliki tanggung jawab terhadap umat (masyarakat).

Terakhir, jiwa yang bebas adalah jalan tengah dari dua prinsip ekstrim, antara jiwa fatal dan jiwa determinan. Pembahasan ini bukan dalam arti ontologis an sich, tetapi harus didudukkan pada konteks historis yang benar. Jiwa bebas Imam Zarkasyi adalah kebebasan orang Indonesia untuk berpikir dan berbuat, menentukan cita-cita dan masa depannya, memilih jalan hidup di masyarakat, dan lebih khusus lagi bebas dari pengaruh asing atau kolonial. Bebas adalah bebas dalam garis-garis disiplin yang positif dan penuh dengan tanggung jawab (Zarkasyi I., 1996: 429). Setiap anak didik, dalam istilah Miskawaih, memiliki potensi hayulani yang beragam diberi ajang aktualisasi $\left(f{ }^{\prime} l\right)$ berbeda pula.

Dilihat dari hirarki nilai Ibnu Miskawaih, kelima nilai wasatiyah (panca jiwa) tersebut menjadi "keutamaan" dan pondasi bagi nilainilai dan karakter-karakter turunan yang lain. Keikhlasan menjadi pondasi bagi nilai dan karakter turunan seperti ikhlas, amanah (dapat dipercaya), bertanggung jawab, integritas tinggi, bekerja keras, dan sebagainya. Orang ikhlas, tidak menuntut pamrih, karena ia terikat niat utama ibadah kepada Tuhan. Kesederhanaan sebagai pondasi nilai dan karakter turunan berupa sikap sederhana, kejujuran, tawadhu', sabar, dan bersyukur. Dengan membiasakan sederhana, hidup apa adanya, orang akan diliputi kesyukuran. Berdikari pondasi nilai dan karakter turunan yakni tangguh, inovatif, kreatif, visioner, solutif, kaya infisiatif, dan inspiratif. Dengan terbiasa mengatasi tantangan hidup akan menjadi tangguh; terbiasa mencari solusi hidup; bahkan mencari inovasi bagi kemajuan. Pikirannya akan senantiasa bergerak, sehingga menjadi kreatif dan visioner. Ukhuwah pondasi nilai dan karakter turunan berupa sikap komunikatif, empati, tidak egois, simpati, memiliki banyak jaringan kerja, optimis, berwawasan luas, dan karakterkarakter sosial yang lain. Ukhuwah menuntut sikap bersosial, hubungan antarindividu, komunikasi, sikap empati, rasa simpati membantu, dan tidak menjadi egois. Kebebasan adalah pondasi nilai dan karakter 
yang bebas, disiplin, arif, bijak, dan tidak aniaya. Dengan kebebasan yang positif, orang akan terbiasa disiplin, ia akan bijak dalam menghargai kebebasan orang lain pula, tidak akan berlaku aniaya, melukai atau merugikan orang lain.

\section{Kurikulum ala Pesantren Gontor}

Kurikulum (disebut manhaj atau al-manhaj al-dirasiyat atau kurikulum pendidikan) pesantren Gontor adalah kurikulum yang integral, memadukan dua hal fundamental, yakni sistem pendidikan kepesantrenan dan materi pendidikan. Keduanya terangkum menjadi al-manhajal-dirasiyat seutuhnya. Al-manhaj al-dirasiyat tidak semata elemen kognitif pendidikan, sebab dipadukan dengan the hidden curriculum dan disokong sistem pendidikan asrama dan kepesantrenan. Sistem pendidikan asrama men-supply kurikulum total dan holistik selama 24 jam, sedangkan sistem kepesantrenan men-supply ketrampilan soft skill yang tidak didapatkan dari kurikulum akademik. Kurikulum ideal menurut Ibnu Miskawaih, baik kurikulum fikriah atau intelektual, kurikulum jasmaniah atau fisik, maupun kurikulum ijtima'iah atau sosial semua dipenuhi dalam totalitas kurikulum Pesantren Gontor. Segala bentuk pelajaran di Gontor kompatibel dengan pengembangan akhlak seperti dikonsepsikan Ibnu Miskawaih. Dalam kurikulumnya, setiap mata pelajaran yang diajarkan memiliki tujuan akhlak. Sesuai prinsip umum Ibnu Miskawaih, ilmu apapun terbuka untuk pendidikan akhlak, asalkan didasarkan pada pengabdian yang tulus kepada Tuhan.

Integrasi pengetahuan yang menjadi ciri kemodernan yang hendak ditransformasikan ke dalam masyarakat. Modernisasi pesantren diharapkan melahirkan manusia Indonesia yang memiliki kepribadian holistik, yaitu kepribadian yang memiliki keseimbangan antara aspek spiritual, aspek intelektual, sosial, emosional, dan fisik. Dalam bahasa Ibnu Miskawaih, sebagaimana yang sering digunakan pula dalam berbagai literatur sufisme, adalah pribadi insan kamil atau orang yang sempurna. Tentang aspek sistem pendidikan pesantren dan aspek kurikulum integratif dan non-dualistik, dan konsep insan kamil, keduanya memiliki titik temu, meskipun tidak bisa disamakan. Insan kamil (orang 
dengan karakter akhlak mulia), dalam pemikiran Ibnu Miskawaih, adalah tingkat spiritual yang dicapai bukan melalui model sistem kepesantrenan ala Imam Zarkasyi. Melainkan, insan kamil adalah orang yang memiliki wawasan spiritual sebagai hasil aktualisasi nafs natiqah atau gerak dauriyah (pendidikan ruhani), sehingga dengan optimalisasi nafsu natiqah-nya ia memiliki hikmat bersifat praksis yang menuntun pada kebijaksanaan.Ibnu Miskawaih tidak memiliki model pendidikan ruhani ala pesantren. Pendidikan akhlak tidak hanya tanggung jawab orangtua dan guru. Lingkungan, termasuk kondisi politik, ikut berperan bagi terjuwudnya tujuan pendidikan akhlak (Suwito, 2004:131). Aspek spiritual diharapkan memiliki dampak moral. Imam Zarkasyi membangun karakter dari pengalaman sosial, emosional, intelektual, spiritual dalam lingkungan pesantren. Dalam istilah Zamaksyari Dhofier, pendidikan Miskawaih yang sufistis lebih mirip dan sesuai dengan pendidikan salaf, bukan pendidikan khalaf atau modern seperti digagas Imam Zarkasyi. Tujuan yang sama tidak mesti dicapai dengan cara yang sama.

Konsep pendidikan pesantren khas Indonesia dan tidak dijumpai di tempat-tempat lain, khususnya tempat Miskawaih lahir, Iran. Pendidikan pesantren dalam menciptakan insan kamil, dapat digambarkan berikut:

"Insan kamil tidak terbentuk secara instant, tetapi memerlukan proses yang cukup panjang. Proses ini berupa transfer of knowledge and inculcation or moral values from one generation to another generation. Dengan pengertian yang lain, merupakan proses transfer ilmu pengetahuan dan penanaman nilainilai moral dari satu generasi ke generasi yang lain. Inilah yang menjadi esensi pendidikan pesantren. Supaya proses ini dapat berjalan secara efisien, diperlukan lingkungan pendidikan (al-bi'ahal-tarbawiyah/environment) yang kondusif, kurikulum yang integratif dan komprehensif, atmosfer akademik yang dinamis, tenaga pengajar yang profesional, fasilitas pendukung belajar yang memadai, dan yang lebih penting lagi adalah pembiasaan (conditioning) melalui kete- 
ladanan para pendidik di pondok pesantren" (Zarkasyi A. S., 2005: xii).

Lingkungan pendidikan yang kondusif dan berbasis pesantren tidak terdapat dalam pemikiran Miskawaih. Namun, dalam integrasi keilmuan keduanya memiliki kesamaan. Seperti Ibnu Miskawaih, ilmuilmu agama atau ilmu-ilmu kealaman keduanya saling mendukung untuk membangun karakter dan moral, asal dihayati dan diterapkan dengan benar, dan untuk pengabdian(ibadah) kepada Tuhan.

\section{Imam Zarkasyi bukan al-Mu'allim al-Hakim}

Kyai sebagai figur sentral dalam pondok pesantren, bisa berperan sebagai guru, pemimpin, teladan, pembimbing, orang tua santri, bahkan personal enterprisebagi pondok pesantren. Bagaimana peran Imam Zarkasyi dalam proses pendidikan? Bagaimana peran itu dilihat dari sudut pandang Ibnu Miskawaih?

Dalam proses pendidikan, Imam Zarkasyi berperan sebagai pengajar. Ia menulis berbagai buku bahan ajar. Dalam biografi (1996: 254) tercatat lebih dari 20 tulisannya dijadikan rujukan pembelajaran di pesantren Gontor, mulai dari Durus al-Lughah al-'Arabiyah, Ilmu Figh, Ilmu Tajwid, Ushuluddin, hingga kumpulan makalah dan pokok pikirannya. Ia mentransformasi nilai-nilai akhlak atau sebagai pengasuh, menggantikan peran utama orangtua dalam pendidikan yang pertama yaitu keluarga. Ia mengasuh santri sejak santri setaraf masa baligh, seperti dimaksud Ibnu Miskawaih, ketika sudah timbul rasa "malu" dan ketika nafsu bahimiyyat bergejolak. Ia juga guru teladan bagi santri-santri, khususnya dalam urusan manajemen dan birokrasi sosial kemasyarakatan, menjadi panutan dalam penerapan nilai-nilai panca jiwa.

Dalam peran-peran tersebut Imam Zarkasyi mirip dengan guru dalam konsepsi Ibnu Miskawaih, guru ideal atau al-mu'allim al-hakim yang mencapai taraf kenabian atau sosok seorang filsuf ideal. Benarkah?

Hemat penulis, dengan mengimajinasikan pertanyaan kepada Imam Zarkasyi, "Apakah Anda seorang $m u^{\prime}$ allim al-hakim atau filsuf 
ideal yang spiritualitasnya mencapai maqam kenabian?"maka ia akan menampik hal itu dan mengatakan "tidak". Ia mungkin "guru biasa" dalam konsepsi Miskawaih. Meskipun memiliki kesamaan orientasi dalam pembangunan akhlak, tetapi mereka menempuh arus pendidikan berbeda. Imam Zarkasyi memilih jalur praksis, menempuh jalan kongkret, sedang Miskawaih menempuh jalur spiritualitas dan tasawuf. Konsep guru ideal tidak ada dalam pemikiran Imam Zarkasyi. Kemuliaan akhlak seharusnya ditempuh melalui pembiasaan akhlak dan implementasi nilai-nilai moral dalam pendidikan, bukan dengan rekonsiliasi dan aktualisasi jiwa syahwatiyyah, ghadabiyyah, dan natiqah sebagaimana Ibnu Miskawaih. Sikap yang membangun jiwa, bukan jiwa diasah untuk membangun sikap.

\section{Tinjauan aspek metodologi pendidikan akhak}

Pandangan Imam Zarkasyi, at-thoriqoh ahammu minal-maadah, metode lebih penting daripada bahan ajar. Cara menyampaikan materi dengan benar akan memberikan pengertian dan pemahaman lebih baik dalam benak anak didik. Metode menjadi penekanan Ibnu Miskawaih yang harus dilaksanakan dengan baik seiring terbukanya kemungkinan perubahan akhlak dalam diri manusia.

Imam Zarkasyi menerapkan metode 6P (peneladanan, pembentukan lingkungan pendidikan, pelatihan dan pembiasaan, pembimbingan, perhatian, dan penghukuman) dalam pendidikan akhlak. Dalam melengkapi unsur-unsur akhlak yang thabi'i (yang terkandung dalam jiwa syahwatiyyah, ghadabiyyah, dan natiqah), Ibnu Miskawaih juga menerapkan "metode tambahan" berupa pembimbingan, pengancaman atau penghardikan, dan penghargaan atau pujian, pembiasaan, pelatihan, dan'adat wa al-jihad, yaitu pengertian jihad ruhani (bahasa jawa:laku).

Metode pendidikan akhlak Ibnu Miskawaih memiliki dua konteks, yakni: metode yang sepatutnya dilaksanakan dalam hal pencapaian akhlak mulia (ditujukan untuk anak usia remaja) dan metode yang harus diterapkan dalam hal perbaikan akhlak atau pengobatan akhlak yang buruk (ditujukan untuk orang yang sudah remaja dan menjelang tua) (Suwito, 2004: 135). Keduanya tidak bisa dipersamakan, sebab per- 
masalahan dan kondisi yang dihadapi juga berbeda. Dalam perbaikan akhlak (Suwito, 2004: 136), Miskawaih memberi terapi 'adat wa al-jihad, yaitu pengendalian diri dan nafsu melalui metode jiwa, seperti puasa, amalan ruhaniah yang ketat dan kuat, juga metode "pencerminan diri" berkaca pada orang lain untuk memperbaiki diri, muhasabat al-nafs atau introspeksi metode mencari aib dan kekurangan diri, serta metode oposisi atau melawankan akhlak buruk dengan amal-amal baik dan mulia dan menggali pengetahuan yang bersifat teoritis terapis. Metode dauriyah semacam itu terlalu berat dan panjang. Sehingga Ibnu Miskawaih memberikan perhatian khusus pada pendidikan remaja, asumsinya apapun yang berat dan panjang asalkan dilakukan semenjak kecil akan terasa ringan dan mudah. Ibnu Miskawaih baru membicarakan metode-metode khusus berupa pembiasaan, pelatihan, dan seterusnya. Pembiasaan sejak dini, anak atau remaja akan terbiasa dengan amalan dan akhlak yang mulia sehingga mudah untuk mencapai akhlak yang mulia. Ungkapan Imam Zarkasyi bahwa "pondok pesantren bukanlah sebagai "bengkel" yang begitu saja bisa merubah seseorang yang sudah rusak menjadi baik" menunjukkan keberpihakan pada pendidikan sejak usia dini dan remaja, seperti dikehendaki Ibnu Miskawaih. Bahwa metode pengajaran atau pendidikan mengikuti perkembangan jiwa manusia.

Di pesantren Gontor, santri dibekali pendidikan agama secara maksimal selama enam tahun, mulai dari hal praksis (peribadatan), teoritis (ijtihad, istimbath), bahkan komparatif (perbandingan madzhab agama). Mereka digembleng dengan metode "6P": Pembentukan lingkungan pendidikan dengan masjid jami' sebagai pusat kegiatan dan peribadatan; pembiasaan dan pelatihan mengaji dan sholat berjama'ah setiap hari dan tepat waktu, dilatih berpuasa sunnah; pembimbingan langsung mulai dari tingkat asrama hingga guru-guru dan kyai, dibimbing belajar siang dan malam; perhatian dengan evaluasi di dalam maupun di luar kelas; penghukuman mulai dari hukuman fisik hingga hukuman aib (social punishment). Dengan seluruh kegiatan itu, akhlak dan moral mereka terbentuk, mereka dilatih mencapai keutamaan jiwa al-bahimiyyat dan al-ghadabiyyat. Peneladanan sebagai metode utama diterapkan dengan konsep "ibda' min nafsik", memulai segala sesuatu 
dari diri sendiri, seperti juga ditekankan Ibnu Miskawaih (Suwito, 2004: 146) dalam mencapai keutamaan al-nafs al-bahimiyyat dan al-ghadhabiyyat. Dengan keteladanan atau peneladanan, anak remaja akan taklid kepada guru dan orang yang diidolakan atau dijadikan panutan. Masa taklid ini akan sangat berpengaruh terhadap perkembangan selanjutnya. Bagi Miskawaih, metode pendidikan akhlak yang tepat untuk anak usia remaja adalah metode panutan (peneladanan) dan doktriner, seperti dilakukan Imam Zarkasyi.

\section{Kepemimpinan sebagai karakter unggul}

Kepemimpinan merupakan satu karakter unggul yang terkait dengan pandangan relasional antara akhlak dan umat (baca: masyarakat). Metode transformasi kepemimpinan atau kaderisasi pemimpin dengan pengarahan, pelatihan, penugasan, pembiasaan, pengawalan, peneladanan atau uswah, dan pendekatan, yang dijalankan dalam arus disiplin yang ketat dan penuh kesadaran. Hasilnya karakter kepemimpinan yang sangat menonjol. Falsafah kepemimpinan yang diterapkan: "mau memimpin dan siap dipimpin, patah tumbuh hilang berganti" (Zarkasyi A. S., 2011: 105). Gontor juga mewarnai lahirnya konsep kepemimpinan "ing ngarso sung tulodho, ing madya mangun karsa, tut wuri handayani", melalui Ahmad Sahal (Zarkasyi A. S., 2011: 11).

Filsafat pendidikan akhlak Ibnu Miskawaih tidak membahas konsep kepemimpinan secara eksplisit, apalagi metode pelatihan kepemimpinan sebagaimana Imam Zarkasyi. Miskawaih hanya mengunggulkan tiga nilai yang utama dari ketiga nafsu inti manusia, yaitu nilai kebijaksanaan, keberanian, dan menjaga kesucian diri atau 'iffah. Ibnu Miskawaih menekankan adanya "puncak keutamaan" atau jalan tengah dari ketiganya, yaitu keadilan (justice). Meskipun konsep keadilan dan konsep kepemimpinan berlainan, tetapi keadilan sebagai sifat utama yang integral, menurut Miskawaih, akan sangat bermanfaat bagi seorang pemimpin ketika memimpin umat atau masyarakat seperti dicita-citakan Imam Zarkasyi.

Pemimpin yang dapat mencapai keadilan dinamakan dengan imam 'adil atau pemimpin yang adil, yaitu pemimpin yang konsisten 
menerapkan prinsip panca jiwa, karakter pemimpin yang ikhlas, sederhana, berdikari, berjiwa sosial, dan bebas dengan segala keutamaannya. Yang ingin dicetak Imam Zarkasyi adalah seorang yang memiliki karakter kepribadian yang matang dan mulia (insan kamil), yang bisa menerapkan keutamaan pribadi dalam kepemimpinannya atas umat dan masyarakat. Dua aspek manajemen kepemimpinan Imam Zarkasyi, yaitu aspek metodis dan aspek material, melalui penerapan konsep 'adat wal jihad di pesantren Gontor; adat sesungguhnya mengacu pada pembiasaan, sedangkan jihad mengacu pada kesungguhan. Ini sejalan dengan konsep pendidikan akhlak Ibnu Miskawaih yang membagi ke dalam dua fase: Fase remaja dengan kecenderungan bahimiyyat dan ghadabiyyat muncul dan menggelora, diperlukan materi agama (syari'at) yang kuat agar kedua nafsu itu teraktualisasi dengan benar. Fase pengembangan intelektual atau daya berfikir (nafs natiqah) bertujuan agar nafs natiqah atau daya intelektual mampu mencapai tingkat "kebijaksanaan", dengan diajarkan filsafat (philosophy). Perpaduan pengetahuan agama (syari'at) dan filsafat (philosophy), akan menjadikan pemimpin bermoral, kader "agamawan yang intelek", bukan "intelek yang tahu aga$m a^{\prime \prime}$.

Dalam character building atau pendidikan aklak, Imam Zarkasyi dan Ibnu Miskawaih memberikan perhatian besar kepada pentingnya karakter dalam diri manusia. Upaya utama dengan menjalankan proses pendidikan. Konsep paling menonjol dan menjadi oritentasi besar di Gontor adalah konsep kepemimpinan, menciptakan generasi pemimpin umat dan masyarakat yang berkarakter dan berbasis pada agama. Konsep kepemimpinan berkarakter yang digagas Imam Zarkasyi sangat relevan untuk menjawab krisis multidimensi yang dialami bangsa Indonesia saat ini.

\section{SIMPULAN}

Sistem pendidikan berbasis pesantren modern merupakan pendidikan yang ideal, atau paling tidak bisa menjadi alternatif dan sumbangan idiil, bagi pembangunan karakter bangsa. Model pendidikan ini unggul dalam hal karakter "kepemimpinan". Wawasan kepemimpinan didasarkan pada nilai-nilai yang luhur dan sistematis. 
Model pendidikan berbasis pesantren penting karena beberapa alasan: Pertama, bangsa Indonesia membutuhkan alternatif bagi pendidikan yang kolonialistik dan instrumentalis. Model pendidikan pesantren mengenal metode pengajaran intelektual ( $\mathrm{ta}$ 'lim), metode tadris (pengamalan atau aplikasi ilmu), $t a^{\prime} d i b$ (pendidikan akhlak dan karakter), tarbiyah (pendidikan spiritual), dan tabligh (transformasi ilmu dan nilai). Kedua, dalam situasi krisis kepemimpinan dan keteladanan, dibutuhkan pendidikan berorientasi kognitif, mengembangkan mentalitas dan karakter individu,mampu menciptakan kader dan generasi pemimpin bangsa yang bermental "memimpin" dan "memperbaiki" kehidupan.Pesantren terbukti melahirkan tokoh-tokoh pemimpin yang memiliki integritas tinggi yang mau dan mampu "menyerbu masyarakat". Ketiga, agama menjadi salah satu basis dasar dari nilai dan moralitas. Sistem pendidikan yang dibangun berlandaskan nilai-nilai keagamaan, seperti pesantren modern, memiliki peluang memberikan sumbangan positif bagi bangsa dengan menciptakan anak didik yang memiliki idealisme dan pandangan hidup bahkan jiwa nasionalisme. Pesantren adalah warisan asli bumi nusantara memiliki tradisi yang kuat di Indonesia, pantas dibanggakan dan dijaga.

Pendidikan yang dijalankan di atas nilai-nilai keislaman dan kemodernan (nilai keikhlasan, kesederhanaan, kemandirian, persaudaraan, dan kebebasan) sangat dirindukan di tengah surutnya moralitas publik dan krisis keteladanan di Indonesia. Pondok pesantren Gontor melakukan transfer of knowledge dan transfer of values and spirits yang sangat esensial dalam pendidikan karakter. Usaha national healing perlu dilakukan dengan membawa nilai-nilai spiritual dan etis ke dalam wacana publik. Sistem pesantren menciptakan santri yang berkarakter, mandiri, dan toleran, melalui proses transfer of knowledge dan transfer of values yang menjadi tujuan utama. Salah satu healing adalah membangun sistem pendidikan karakter, khususnya yang membekali wawasan kepemimpinan.

\section{DAFTAR PUSTAKA}

Alhamuddin, 1428 H, Pendidikan Islam Modern ala Trimurti: Pondok Modern Gontor, tt. 
Ali, Mukti, 1991, Ta'lim al-Muta'allim versi Imam Zarkasyi, Trimurti Press, Gontor.

As-Sidqy, H., 2004, K.H.Imam Zarkasyi's Concept on Moral Education (Thesis), Faculty of Education, Ponorogo.

Basyir, A., 1983, Filsafat Islam, Proyek P3T UGM, Yogyakarta.

Djumhur, dkk. , 1976,Sejarah Pendidikan (IX ed.), CV Ilmu, Bandung.

Duady, A., 1986, Kuliah Filsafat Islam, Bulan Bintang, Jakarta.

Haikal, 1996, "Percikan Pemikiran K.H.Imam Zarkasyi Sebagai Pendidik Teladan yang Dilupakan" dalam Tim Penulis, K.H.Imam Zarkasyi di Mata Umat, Gontor Press, Ponorogo.

Latif, Yudi, 2007, “Hancur Karakter, Hancur Bangsa: Urgensi Pendidikan Karakter", Majalah Basis ( edisi Juli-Agustus).

Majid, dkk., 2005, Pendidikan Karakter Perspektif Islam, Remaja Rosdakarya, Bandung.

Miskawaih, Ibnu., 1994, Menuju Kesempurnaan Akhlak (terj. H. Hidayat) Mizan, Bandung.

Miskawaih, Ibnu., 1398 H, Tahdzib al-Akhlaq (terjemahan S. H. Tamir), Mansyurat Dar Maktabat al-Hayat, Beirut.

Nata, Abuddin, 2000, Akhlak Tasawuf(III ed.), Raja Grafindo, Jakarta.

Sirojuddin, 1996, “Ketika Imam Zarkasyi Bilang "Tidak!"”, dalam Tim Penulis, K.H.Imam Zarkasyi di Mata Umat, Gontor Press, Ponorogo.

Suwito, 2004, Filsafat Pendidikan Akhlak Ibn Miskawaih, Belukar, Yogyakarta.

Tim Penulis, 1996, K.H.Imam Zarkasyi dari Gontor Merintis Pesantren Modern (I ed., Vol. I), Gontor Press, Ponorogo.

Yunus, M., 1979, Sejarah Pendidikan Islam di Indonesia (2 ed.). Mutiara, Jakarta.

Zarkasyi, Abdullah Syukri, 2005, Manajemen Pesantren: Pengalaman Pondok Modern Gontor, Trimurti Press, Ponorogo.

Zarkasyi, Imam., 1996, “Tentang Pembaharuan Pendidikan Nasional” dalam Tim Penulis, K.H. Imam Zarkasyi dari Gontor Merintis Pesantren Modern, Gontor Press, Ponorogo. 
Zarkasyi, Imam., 1996, "Definisi dan Isi Panca Jiwa Pondok Pesantren" dalam Tim Penulis, K.H. Imam Zarkasyi dari Gontor Merintis Pesantren Modern, Gontor Press, Ponorogo.

Zarkasyi, Imam, tt, Diktat Khutbah al-Iftitah dalam Pekan Perkenalan KMI Pondok Modern Gontor, Sektretariat Pondok Modern Gontor, Ponorogo.

Zarkasyi, Imam, dkk., tt, Wasiat, Pesan, Nasehat dan Harapan Pendiri Pondok Modern Gontor, Pondok Modern Darussalam Gontor, Ponorogo.

Ziemek, M., 1986, Pesantren dalam Perubahan Sosial, P3M, Jakarta. 